\title{
Feminin ledelse \\ - hvorfor er det et problematisk koncept?
}

Af Yvonne Due Billing

Feminin ledelse - realitet eller blàlys? Cementerer konsstempling af adfard og karaktertrak konservative opfattelser af femininitet og maskulinintet således, at ligestilling af kvindelige ledere kun kan opnas som et resultat af fastlaiste konsnormer? ¿edelse er domineret af mænd - og ledelse er (eller har primært været) konstrueret i maskuline termer. Dette har marginaliseret, hvad der socialt er blevet forstået som ikke-maskulint og gjort det vanskeligere for kvinder at blive rekrutterede til og fungere $i$ et lederjob. I de senere år har der dog været lanceret nogle ideer om feminin ledelse, hvilket kan ses som en udfordring til den dominerende diskurs og dermed også progressivt med hensyn til at gøre det lettere for kvinder at opnå positioner på højere niveauer og at fungere i disse. Desuden kan det måske også være en medvirkende faktor til at organisationerne efterhånden kan forandres $\mathrm{og}$ blive mere humane, familievenlige, fleksible, hvor medarbejdernes ve og vel har større betydning end i dag.

Den tese, jeg vil fremføre, er imidlertid, at vi nok ikke skal forvente radikale forandringer af organisationerne, fordi flere kvinder bliver ledere, eller at de kan bidrage med noget særligt, der kan skabe nogle go- 
de organisationer. Især er konceptet feminin ledelse misvisende og problematisk, når vi beskæftiger os med ligestilling. I det følgende skal jeg kritisk diskutere ideer om feminin ledelse og argumentere for, at der er andre måder at forholde sig kritisk til ledelse end ved at anvende begrebet feminin ledelse som et slogan for at promovere ligestilling, øget effektivitet osv. Pointen er ikke at afvise konceptet, men problematisere og diskutere det, anerkende at der er positive, men altså også negative måder at anvende det på.

Hovedpointen er, at de dominerende værdier i vores samfund (som understøttes ikke bare af mange mænd, men også af mange kvinder) bør gennemdiskuteres meget mere grundigt, end det er muligt, når man anvender et snævert kønsvokabularium. De samfundsmæssigt bredt accepterede værdier - som vækst, udnyttelse af naturen, hedonisme, overflodskonsumption og karriereorientering, som er fastforankrede i den måde kapitalismen og markedsøkonomien fungerer på - ser ud til at være de væsentligste forhindringer for radikale forandringer. Når sådanne værdier er bredt accepterede - værdier, som er funderet i den instrumentelle rationalitets dominans og prioriteringen af det materielle - betyder det, at der er en ubalance mellem, hvad der ofte refereres til som feminint og maskulint, og denne ubalance fastholder ulighederne mellem mænd og kvinder og (re)producer globale uligheder.

I det følgende vil jeg diskutere fænomenet feminin ledelse $\mathrm{i}$ en bredere og mere kritisk kontekst og argumentere for, hvorfor vi er nødt til at være meget forsigtige, når vi kønsstempler ting/adfærd, og jeg vil hævde, at begrebet feminin måske ender op med at være mere diskriminerende end det modsatte, hvis vi benytter det i relation til ledelse.

\section{LEDELSE OG MASKULINITET}

Ledelse har traditionelt og historisk været konstrueret i maskuline termer. En maskulin etik var en del af det tidlige image (Kanter 1977). Den numeriske dominans af mænd og deraf følgende konstruktion af ledelse inden for en maskulin referenceramme har haft betydning for antallet af kvinder i ledelse. Selvom der er sket betragtelige forandringer i de senere årtier, er kvinder fortsat i mindretal i de mest magtfulde positioner. Dominansen af mænd, samt dybt rodfæestede kulturelle ideer om kvinder og mænd, giver ledelse et maskulint image (Collinson and Hearn 1996). Magt og status er knyttet til jobbet, og indholdet af ledelse er på forhånd givet, ved at bestemte 'typer' af mænd har (haft) disse positioner eller blevet anset for passende til disse. Dette bliver så standarden i forhold til, hvordan andre kategorier bliver vurderet. Dette kan betyde, at kvinder (så vel som arbejderklassemænd og medlemmer af nogle etniske grupper) har sværere ved at få sådanne jobs, og der kan også være fordomsfulde evalueringer.

Hvad menes der egentlig med maskulinitet (femininitet)? Disse kategorier er kulturelt definerede, "created, together, out of a complex of dynamic intervowen, cognitive, emotional, and social forces" (Keller 1985). Det feminine og det maskuline anses ofte for at være gensidigt ekskluderende og ofte essentialistisk relateret til kvinders og mænds kroppe.

En typisk beskrivelse af maskulinitet er følgende: "Hard, dry, impersonal, objective, explicit, outer-focused, action-oriented, analytic, dualistic, quantitative, linear, rationalist, reductionist and materialist" (Hines 1992, 328). Marshall (1993) mener, at det mandlige princip står for: "Self-assertion, separation, independence, control, competition, focused perception, rationality, analysis" (s. 124). Kerfoot \& Knights (1996, 79) mener, at maskulinitetens kerne i ledelse er "a preoccupation with a particular instrumental form of "rational control"'.

Maskulinitet/femininitet er konstant under forandring og kulturelt og historisk af- 
hængige af de betydninger, vi tilskriver disse. Kimmel (1994) noterer historiske konstruktioner af maskulinitet, og at sameksistensen mellem håndværkerens mandlighed $\mathrm{og}$ patriarkens efterhånden blev truet, da markedets mand trådte ind på den historiske arena. Kimmel mener, at markedsmaskuliniteten må anses for at være den normative definition på amerikansk maskulinitet, og at dennes karakteristik "aggression, competition and anxiety" sætter standarden for andre mænd. "The hegemonic definition of manhood is a man in power, a man with power, and a man of power" (s. 125).

Maskulinitet er dog ikke forbeholdt mænd. Fagenson \& Jackson (1993) refererer undersøgelser, der viser "the more "masculine" characteristics possessed by women, the more likely the women are to be perceived as successful managers and located in powerful corporate positions' (s. 315). De nævner bøger og kurser, som er 'designede' for at hjælpe kvindelige ledere med at udvikle såkaldte maskuline træk. Kvinder, som har succes som ledere udøver ifølge Cheng (1996) hegemonisk maskulinitet.

At udøve hegemonisk maskulinitet er ikke omkostningsfrit. Kaufman (1994, 148) mener, at man derved kommer til at undertrykke "a range of emotions, needs, and possibilities, such as nurturing, receptivity, empathy, and compassion, which are experienced as inconsistent with the power of manhood." At undertrykke disse følelser og kvaliteter kan meget vel være usundt. Kaufmann (1994) mener, at mænd undertrykker følelser, fordi følelser associeres med femininitet. Maskulinitet bliver ofte betragtet som antitetisk til femininitet.

Indtil videre har vi fået et relativt enkelt billede af maskulinitet. Det skal nu kompliceres yderligere.

For det første ser der ud til at være tegn på et opbrud i den stærke polarisering mellem maskulinitet og femininitet. Den nuværende ledelsesdiskurs ser ud til at være mere i harmoni med, hvad der inden for kønsforskningen ofte refereres til som feminine værdier og orienteringer, selvom der ikke foretages denne eksplicitte kobling til køn, hvis vi bevæger os uden for kønslitteraturen (Blomqvist 1994, Fondas 1997). Mandligt dominerede organisationer kan også fejre intuition, kreativitet, relationsorientering og anerkende betydningen af følelser osv. (Alvesson 1998). Ledelse beskrives mindre og mindre i maskuline termer.

For det andet er det klart, at kvinder i ledelse ikke nødvendigvis har feminine orienteringer. Dette er muligvis også under forandring, hvis rekonstruktion af ledelse $\mathrm{i}$ mere pro-feminine termer tilbyder flere muligheder for sådanne identifikationer. Men tilgængelige studier af kvindelige ledere indikerer, at de ofte har eller udvikler orienteringer, som er mere maskuline end feminine.

På trods af flere indikationer på at kvinder i ledelsespositioner typisk har identificeret sig med det maskuline, har det i forskningen og i mere populære skrifter været hævdet, at kvinder har en forskellig ledelsesstil fra mænd ofte refereret til som feminin ledelse.

\section{FEMININ LEDELSE}

Den nuværende interesse i nye ledelsesideer ser ud til at være sideløbende med en interesse $\mathrm{i}$ feminin ledelse og i at få flere kvinder i ledelse. En forestilling om at ledelse er under forandring tilbyder en mulighed for at fremme kvinders karrieremuligheder. I dag ser vi en stærk tendens til at beskrive forskelle mellem kønnene; forskelle der forklares vha. kønsstereotyper (f.eks. i Grant 1988, Helgesen 1990). En fremherskende tanke er ideen om feminin ledelse.

Femininitet defineres ofte i komplementære termer til maskulinitet. Hines (1992, 314) definerer femininitet som "the prioritizing of feelings..the importance of the imaginative and creative..". Det feminine er 
ifølge Marshall (1993, 124) karakteriseret af "interdependence, cooperation, receptivity, merging, acceptance, awareness of patterns, wholes and contexts, emotional tone, personalistic perception, being, intuition, and synthesizing" og i følge Grant (1988) af omsorg, sensitivitet og empati.

Dette betyder, ifølge Grant, at kvindelige ledere i særdeleshed kan bidrage med egenskaber som: "Communication and cooperation, affiliation and attachment, power, and intimacy and nurturance". Grant (og mange andre) mener, at kvinder ofte har en anden holdning til magt end mænd, som ikke er forbundet med dominans og mulighed for kontrol, men som mere relationelt og mindre individualistisk.

Fagenson $(1993,5)$ er nået frem til, at kvindelige ledere ofte udøver et mere demokratisk og ikke-hierarkisk lederskab samt har flere tilfredse medarbejdere. Helgesen (1990, 38-39) definerer "feminine principles" som "principles of caring, making intuitive decisions...having a sense of work as being part of your life, not seperate from it; putting your labor where your love is; being responsible to the world in how you use your profits." Helgesen fremhæver kvinder som mere omsorgsfulde, involverede og lyttende. I Helgesens terminologi bliver den kvindelige leder den gode moder.

Ifølge Rosener (1990, 120) mener kvinder, at de er interaktive, "they actively work to make their interactions with others positive for everyone involved." Kvinderne i hendes undersøgelse fremhævede det at opmuntre deltagelse, dele magt og information, forstærke andre menneskers selvværd og få andre til at blive engageret i deres arbejde.

Disse specifikke orienteringer forstås som dannet enten i den tidlige barndom, hvor separations-individuations processen er mere kompleks for piger og fører til mere udtalt omsorgsorientering blandt mange kvinder, eller de stammer fra erfaringer med familiesfæren og især med børn.
Den nævnte litteratur er temmelig generaliserende med mange stereotype ideer. Typisk er der ingen distinktioner mellem forskellige grupper af kvinder (eller mænd) eller historisk og kulturelt forskellige kontekster. Der er således en tendens til at essentialisere køn.

Medens de ovennævnte fremhæver kvindelige lederes stil som anderledes end mænds, er der andre studier, der viser et andet billede. De fleste komparative studier af mandlige og kvindelige ledere konkluderer, at der er beskedne om nogen forskelle (f.eks. Dobbins \& Platz 1986, Powell 1988). En vigtig undtagelse er Eagly \& Johnson (1990) som fandt, at kvinder er mere "participation-oriented". Den generelle konklusion er imidlertid, at kvinder og mænd i ledelsesroller har lignende aspirationer, værdier og personlighedstræk så vel som jobrelaterede evner og adfærd.

Dette blev bekræftet på en konference for danske kvindelige ledere (1997). De deltagende kvinder mente, de havde de samme gode muligheder for at blive ledere som mænd, og at der ikke var noget, der forhindrede kvinder i at nå toppen. Men "det er nødvendigt, at kvinder tager ansvar for sig selv og deres liv" og "vi skal lære at forstå, at det er muligt at arbejde 60 timer i ugen og på samme tid være en god moder. Det er alt sammen et spørgsmål om at organisere sig selv, for eksempel med en aupair i huset". Denne konference bekræftede, at kvindelige ledere er meget lig de mandlige, og at de klart accepterer de dominerende værdier og regler i organisationerne.

White (1995) undersøgte, om en gruppe kvindelige ledere anvendte en interaktiv stil, og om der var ledelsesstile, de fandt mindre komfortable. Hun fandt at det eneste, der adskilte dem fra mænd, var deres større grad af engagement i karrieren, organisationen og i medarbejderne. Bayes (1987) nåede til en lignende konklusion, hun fremhævede diversiteten blandt de kvindelige ledere, og som i Whites undersøgelse blev de 
kvindelige ledere opfattet som mere hårdtarbejdende end mændene.

Der er således ikke meget, der støtter den ide, at der er en specific form for feminin ledelse. Måske kan man forstå hele ideen om feminin ledelse som et regulativt ideal, en normativ konstruktion, snarere end et empirisk fænomen. Det hele kompliceres af, at der sandsynligvis er en vis selektion til ledelsespositioner, dvs. de kvinder, som bliver valgt til ledelsesjobs, kan være anderledes end andre kvinder og være mere lig mænd, eller måske bliver de mere lig mænd. Når man bliver leder, kan det ikke forventes, at man overfører nogle bestemte orienteringer til den nye situation, man udvikler og redefinerer orienteringer og handler i overensstemmelse med lokale normer og forventninger, derfor er det vanskeligt og måske meningsløst at sammenligne idealer, subjektiviteter og handlinger fra meget forskellige situationer. Sammenligninger siger måske mere om situationerne end om personerne (Lefkowitz 1994). De fleste har sikkert meget usikre ideer med hensyn til, hvordan de skal udøve ledelse, før de făr jobbet. Hvad vi føler eller tænker om ledelse på et abstrakt niveau er ikke særligt relevant, sammenlignet med hvad vi gør i den aktuelle situation. Sidstnævnte er vanskeligt at forudsige. Og det varierer naturligvis også.

Det er derfor ikke nemt at acceptere ideen om, at der er en slags feminin ledelse, som de fleste kvinder tilslutter sig og som vil blive manifesteret af disse, når de engang opnår nogle ledende positioner og dermed formelle positioner, ud fra hvilke de kan udøve ledelse. En påstand som "the full potential of feminine leadership will only be realized when a large number of women managers begin to assert their true identity and use their special talents" (Sharma, i Townley 1994, 151) er spekulativ og bygger på en antagelse om a) lighed mellem kvinder b) nogle færdige og sande identiteter og talenter og c) at disse vil blive manifesteret uden særlig påvirkning af situatio- nen. Spørgsmålet er, om disse tre antagelser holder. Den mulige forøgelse af antal kvindelige ledere vil blive påvirket af mange andre forandringer, f.eks. i kvinders orienteringer og identiteter.

Det er fristende at hævde, at feminin ledelse er en myte eller en ideologi, som er opfundet af fortalere for flere kvindelige ledere, nogle, som er overbeviste om, at kvinder og mænd er fundamentalt forskellige. Konceptet kan imidlertid også forstås som et konstruktivt modbillede til gamle ideer om ledelse, et modbillede, som kan gøre det nemmere for mange kvinder - og nogle mænd - at identificere sig med ledelse. Her koncentrerer jeg mig imidlertid om problemerne. Dette er velbegrundet, i betragtning af at der er en stor og ekspanderende litteratur, som oftest ukritisk hylder feminin ledelse, og der er mangel på kritisk litteratur om emnet.

Desuden er der al mulig grund til at være skeptisk med hensyn til at forestille sig, at de samme karakteristika (feminine), som tidligere kunne bruges til at diskvalificere kvinder, nu kan blive de karakteristika, som gør det nemmere for kvinder at få adgang til og fungere i ledelsesjobs. Det modsatte argument blev fremfort for 15-20 år siden, hvor kvinders lighed med mænd blev fremhævet, og at de derfor skulle blive ledere, medens det nu hævdes, at kvinders forskellighed fra mænd gør dem til bedre ledere. Det skaber det indtryk, at kvinder kan konstrueres eller rekonstrueres arbitrært for at gøre dem til egnede kandidater til ledelsesjobs.

\section{Nogle PROBlemer MED IDEEN OM FEMININ LEDELSE}

I det følgende vil fire centrale aspekter blive diskuteret: 1) ideen at kvinder har forskellig ledelsesstil baseret på deres forskellige erfaringer 2) problemer med at integrere feminin ledelse med instrumentelle hensyn 3 ) den fare, at ideer om feminin ledelse vil reproducere stereotype forventninger og her- 


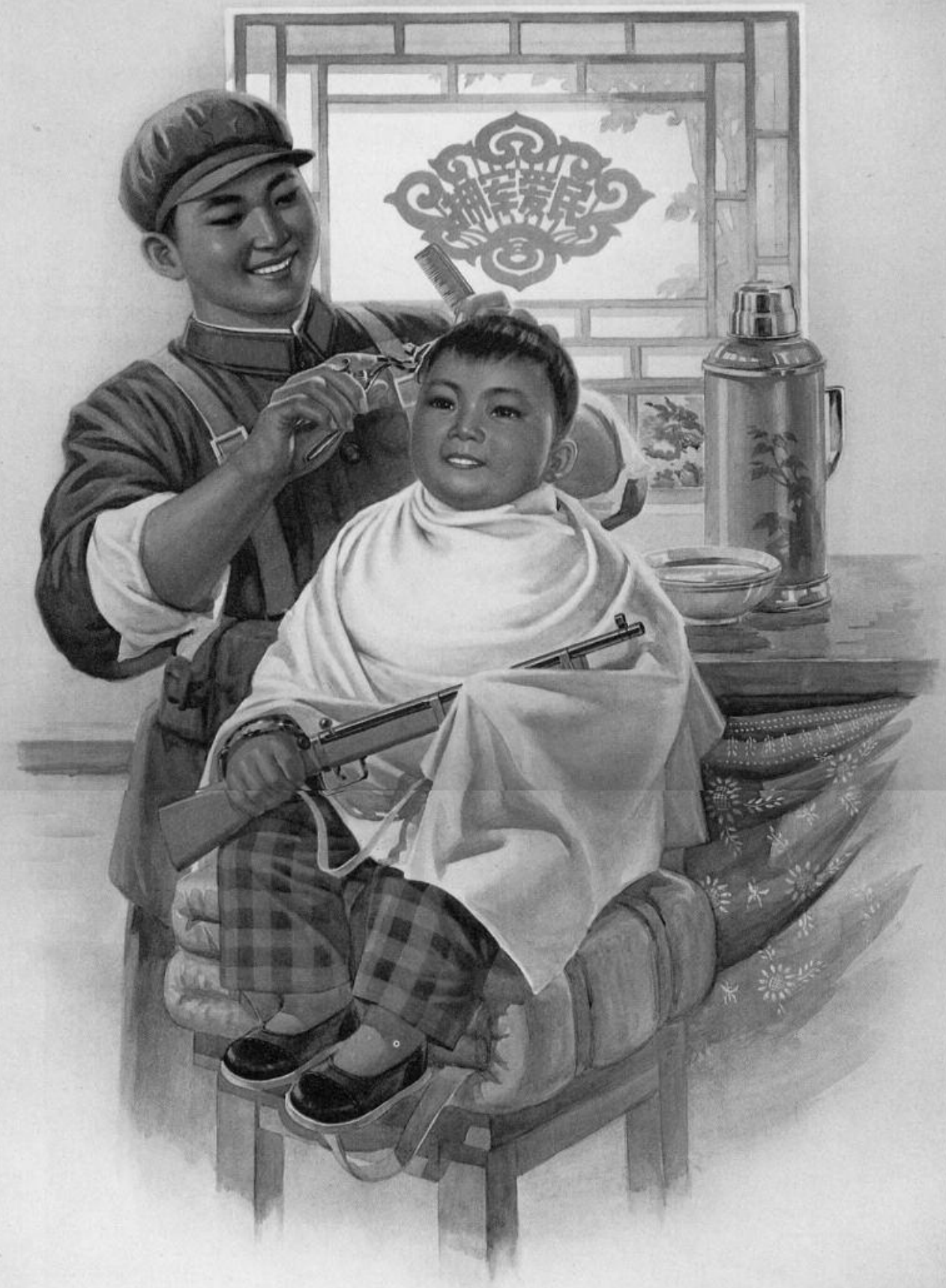

"Heren og folket er én familie”, Finn Suenson Forlag, 1978 
med bidrage til status quo og 4) den mulighed, at ideen om feminin ledelse kan indebære, at kvindelige ledere kan blive udnyttet.

\section{Problemer med basis for feminin ledelse}

Mange forskere mener, at kønsspecifikke orienteringer er betinget af den kønsspecifikke arbejdsdeling. Den primære base for kvinders og mænds forskellige erfaringer og værdier er begrundet i, at mænd og kvinder har udført og fortsat gør forskellige ting i familiearbejdet og på arbejdsmarkedet. Kvinders orienteringer antages at stamme fra familiesfæren især fra pasning af børn (Hartsock 1987). Store kønsforskelle med hensyn til hvilken ledelsesstil, der foretrækkes skulle så være et resultat af, at kvinder primært er ansvarlige for børn og husholdning.

Hvis de evner, der er udviklede i den private sfære eller på andre måder udviklede af kvinder i den tidlige barndom eller gennem socialisation, dels er mulige at overføre, og dels er en fordel, med hensyn til ledelse af organisationer, så kan man spørge, om der er nogen grund til at ændre kønsarbejdsdelingen? De, der er fortalere for feminin ledelse, hævder at det at opdrage børn og tage sig af familie og hjem forer til, at man kan udholde stress, at man er i stand til at klare mange forskellige opgaver, at man har intuition samt kommunikations- og relationsevner (Helgesen 1990, Grant 1988).

At promovere kvindelige ledere ved at fremhæve de fordele, der er forbundet med at have haft det primære ansvar for husholdning og børnepasning, er ikke entydigt positivt, eftersom det trækker på, og på sin vis fejrer kvinders traditionelle positioner, dvs. som primært ansvarlige for børn og hjem (Alvesson \& Billing 1997, Calás \& Smircich 1993). Denne ide indebærer en konservativ normalisering af kvinder som de primære omsorgstagere for børn og familie.
Problemer med at integrere feminin ledelse med instrumentelle bensyn

Det er ikke intentionen helt at se bort fra, at husarbejde og børnepasning kan føre til udvikling af værdifulde sociale evner, men man kan sætte spørgsmålstegn ved, om dette kan overføres til organisationer, især hvis disse opererer ud fra nogle kapitalistiske principper. Hvad der er vigtigt her er, at ressourcer udnyttes effektivt, og at der opnås resultater. Dette indebærer en stærk instrumentel orientering. At reducere omkostninger og udbytte arbejdskraften er ofte vigtige elementer.

Kapitalistisk ledelsesarbejde og familieledelse er meget forskelligt. I 'business' er der et betydeligt konkurrencepres og krav om høj profit, som ikke bare kan ophæves ved at der kommer flere kvindelige ledere. Denne instrumentelle orientering, som kendetegner de fleste organisationer, vil ofte betyde, at arbejde kolliderer med familiens vel og ve. Desuden er evner udviklede i relation til hjemmet måske temmelig perifere sammenlignet med tekniske og mere centrale kernekompetencer. Hvis feminine værdier såsom omsorgs- og relationsorientering mv. ses som centrale evner for kvinder, vil dette måske indebære, at de vil blive betragtet som mere kvalificerede som personalechefer og som ledere af børnehaver o.lign. end som ledere $\mathrm{i}$ industrien og i financielle virksomheder.

Summa summarum må man sætte spørgsmålstegn ved, om det overhovedet er muligt at overføre såkaldte feminine færdigheder, som er baseret på familiearbejde til en organisationskontekst. Sandsynligvis er det nemmest i mere 'familielignende' organisationer. Ideen om feminin ledelse kan således være medvirkende til at reproducere kønsarbejdsdelingen på ledelsesniveauet, eftersom kvindelige ledere vil blive anset for egnede til specielle funktioner og positioner og mindre egnede til de mest magtfulde og prestigeprægede positioner. 


\section{Feminin ledelse stereotypificerer}

Et andet problem er, at ideen om specielle feminine værdier kan forstærke stereotype forestillinger om kvinder. Selvom der er nogle tendenser til, at mænd, respektive kvinder, udtrykker forskelle i værdier, stil eller evner i nogle situationer, er det vigtigt ikke at overdrive dette. Forskelle inden for kønskategorierne er formodentlig større end forskelle mellem kønnene. Som mange kønsstudier har vist, så er kvinder meget forskellige og kan udvikle alle mulige former for orienteringer. Et ideal i kønsstudier kunne være at lade diversitet blomstre i stedet for at etablere standarder og regler for, hvordan man skal være. Dette indebærer forsigtighed med hensyn til at sige noget om, hvad der er 'naturligt' eller 'normalt' for kvinder eller mænd.

Eagly et al (1992) fandt, at kvindelige og mandlige ledere blev evaluerede ens af de underordnede, undtagen når de optrådte med autoritet, hvor kvinderne blev evalueret mere negativt. Ideer om feminin ledelse kan forstærke og legitimere sådanne devalueringer og indsnævre det mulige ledelsesrepertoire. Flere har observeret, at nogle kvinder i ledelse bliver opfattet som 'bossy' eller autoritære. Dette bortforklares typisk ved at henvise til eksterne betingelser såsom behovet for at tilpasse sig mandlige normer (Cockburn 1991), eller at de kvindelige ledere har ansvar, men ikke magt (Stivers 1993). Dette er muligt, men det forstærker antagelsen, at en kvinde ikke normalt handler på denne måde. Men hvorfor skal vi ikke være åbne for den mulighed, at kvinder agerer på en række forskellige måder i ledelsesjobs, som kan have at gøre med deres subjektivitet eller vurdering af, hvad en bestemt arbejdssituation kræver af adfærd?

\section{Kvinders såkaldte specielle evner kan blive udnyttet}

Et lidt andet problem er, at såkaldte feminine talenter kan udnyttes eller misbruges. Kvinder kan meget nemt blive den nødvendige olie, der skal få organisationsmaskine- riet til at fungere bedre. Ligeledes kan forestillinger om kvinders motivations og -overtalelsesevner blive udnyttet f.eks. som et værktøj til at udføre nogle upopulære rationaliseringer mere smidigt, hvor kvindernes rolle kan blive at agere forhandlere mellem topledelsen og arbejderne (Calás and Smircich 1993).

Holmquist (1997) beskriver kvindelige ledere i den offentlige sektor som bødler med en blid hånd. Nedskæringer $\mathrm{i}$ den svenske offentlige sektor kombineret med en stigning $i$ antal sociale problemer betyder, at det er noget af en uriaspost at være leder, når det hovedsageligt drejer sig om at skære ned på servicen. Mange kvindelige ledere internaliserer problemer og skyder skylden på sig selv, hvis det ikke lykkes for dem at få tingene til at fungere. Kolb (1992) viser, hvordan kvinder kan være tilbøjelige til at arbejde med konflikter 'backstage', hvilket kan være vigtigt, men det forbliver ofte usynligt og kan potentielt forhindre, at konflikter kommer op på overfladen.

Kvinder kan naturligvis blive ansat i konfliktløsningspositioner, uanset om man har en ide om feminin ledelse eller ej. Men konceptet fremmer ansættelsen af kvinder i positioner, som har at gøre med relationer, følelser og konfliktløsning - medens de mere substantielle økonomiske og teknologiske emner forbliver mændenes sfære.

\section{Modargument: Nogle positive aspekter}

Ideen om feminin ledelse er ikke kun dårlig, men intentionen med denne artikel er at gøre opmærksom på nogle problemer, eftersom kritikken har været meget begrænset sammenlignet med den enorme og ofte unuancerede litteratur om kvinders dyder som ledere.

Det er positivt, at ideen bidrager til at udfordre traditionelle opfattelser af organisation, hierarki, ledelse. Desuden sættes køn på ledelsesdagsordenen, og derved problematiseres mandlig dominans. Det kan derfor bidrage til demaskulinisering af 
ledelse. Som kritik af dominerende ideer er det dog meget svagt og kan måske endda blive beskrevet som en 'kastreret' version af feminisme (Fletcher 1994), men ideen kan gøre det nemmere for kvinder at komme ind i seniorpositioner $\mathrm{i}$ organisationer. Det kan få flere kvinder til at overveje ledelsesjob, opmuntre mere positive holdninger til kvinder og gøre det nemmere for de, der er i ledelsesjobs at overveje en mindre traditionel stil.

\section{AT KOMME VIDERE END KØNSFORSKELLE}

Det er vigtigt at være forsigtig og tilbageholdende med at anvende koncepterne maskulinitet og femininitet. I stedet for at forbinde disse koncepter til kvinder og mænd, kunne man forstå dem som former for subjektivitet, som er potentielt tilstede hos alle, mænd såvel som kvinder, selvom det er i forskellig grad. Maskuliniteter og femininiteter er ikke essenser. Når kvinder defineres biologisk, anses de typisk for at være mere karakteriserede af femininitet end af maskulinitet, selvom der er variation med hensyn til kompositionen. Nogle kvinder kan beskrives som maskuline i orientering og prioriteringer nogle mænd som mere feminine.

Kvinder såvel som mænd kan agere maskulint eller feminint, instrumentelt såvel som følelsesmæssigt, afhængigt af situationen. Kvinder i kvindedomineret arbejde, f.eks. sygepleje, var mere maskuline i deres ledelsesstil end deres mandlige kolleger (Eagly \& Johnson 1990). Det er vigtigt at anerkende, at der er flere mulige måder at handle på end kønsrollestereotypt, og det er måske muligt at være mere effektiv, hvis man er i stand til såvel at samarbejde og lytte til medarbejderne, som af og til at være mere dirigerende, målorienteret og i stand til at træffe nogle ubehagelige beslutninger. Snarere end at hænge fast i en speciel orientering vil overskridelsen af kønsstereotype standarder kunne åbne op for, at man kan gøre brug af orienteringer, som erfares som relevante og meningsfulde.

De sociale kønskonstruktionsprocesser er komplekse og mangefacetterede. Maskulinitet og femininitet forandres over tid og gennem individers livsforløb og varierer med klasse, race, beskxftigelse, organisation, alder og individuelle betingelser. At knytte maskulinitet til mænd og femininitet til kvinder er uheldigt, da det prioriterer det biologiske køn, og der ses bort fra den enorme variation, der er i konstruktionen af mænd og kvinder. Der er store problemer, når vi skal forsøge at identificere maskuliniteter såvel som femininiteter. Hvordan reflekterer de den sociale virkelighed? Reflekterer de kun nutidige vestlige eller bare nutidige kønsforskeres ideer om, hvad der er maskulint og feminint? eller forskellige religiøse ideer og traditioner? Den kristne tradition har fokuseret på forskelle på kvinder og mænd, medens østens og den oprindelige amerikanske filosofi har fokuseret på overlapning mellem maskulinitet og femininitet og lighederne mellem disse (Gagné and Tewksbury 1996). I nogle ikke-vestlige kulturer er idealet en blanding af feminine og maskuline elementer. I vores del af verden er yin værdier (oprindelse i kinesisk filosofi, hvor yin står for det feminine og yang for det maskuline) blevet undertrykt og domineret af yang værdier. Kinesisk filosofi fremhæver det vigtige $i$ at opnå en balance, "because there cannot be one without the other" (Watts, i Hines 1992). Mange kønsforskere mener med rette, at 'feminine' værdier ikke er værdsat på niveau som maskuline værdier. Et eksempel på dette er Hines, der beskriver 'feminine' værdier således: "Caring, and sharing; the prioritizing of feelings; the reality and value of the nonmarketable and non-material; the importance of the imaginative, intuitive and creative; a vision of the wholeness and interdependence of the world, and a knowledge of and faith in the creative potential of stillness, rest and silence" (Hines 1992, 314). Værdisystemer er imidlertid kulturelle kon- 
struktioner og derfor mulige at ændre, så det der tidligere blev betragtet som negativt kan reevalueres og anskues som positivt.

Køn eksisterer ikke bare som et socialt fænomen, men skabes og genskabes i en fortløbende proces f.eks. på arbejdsmarkedet og i organisationspraksisser. Køn skabes gennem, at kvinder konstrueres som mødre og som familieorienterede, samt ved at de ansættes i kvindejobs, i servicejobs og i underordnede positioner. Ligeledes skabes køn gennem socialisation, hvor kvinder stadig hovedsageligt står for den primære socialisation. Hvis fæedre tog lige så meget del i børnepasning (og moderskab blev til forældreskab), ville subjektdannelsen sikkert se helt anderledes ud.

Det er vigtigt at få ophævet arbejdsdelingen (i hjemmet og på arbejdsmarkedet), da denne deling fastholder uligheder. At hylde specifikke feminine evner og talenter, associeret til kvindekønnet, er i modsætning til dette ideal. Begrebet feminin ledelse, som lig med en 'kvindelig' specialitet, er afledt af opfattelsen af kvinden, som den der gør det meste af husarbejdet og familiearbejdet

Frem for at bruge begreberne maskulin/feminin kunne man anvende Webers rationalitetsbegreber, hvor værdirationalitet er "a characteristic of social action, of interaction, of communication" (Heller 1984, 77). Kriteriet for formålsrationalitet er realiseringen af et givet mål. Problemet er ikke kun, at formålsrationelle handlinger har absorberet værdirationalitet, snarere, mener Heller, er problemet, at: "the problem is far more that this type of activity is preferred even when it is unnecessary, indeed even when it is unacceptable." At formålsrationalitet dominerer skal ses i sammenhæng med vores materielle orientering og tro på, at den kapitalistiske markedsøkonomi er bedst i stand til at skaffe, hvad vi ønsker. Dette kan meget vel være den største forhindring for, at kønsrelationer kan radikalt forandres. Konkurrence mellem virksomhe- der betyder, at det er et stærkt incitament for ledere at foretrække ansatte, som kan prioritere arbejdet. Hvis man har ansvar for små børn, vil man stå dårligere end en, som ikke har den begrænsning. Dette er ikke nødvendigvis et spørgsmål om fordomme eller lignende, men indbygget i markedsøkonomien. Produktivitet og konkurrenceevne er de kriterier ansattes værdi bliver målt efter, ikke evnen til at dele, at vise venlighed, at være empatisk.

Den generelle tendens til, at kvinder er de primære omsorgsgivere, kan føre til, at mange udvikler sådanne evner, men dette behøver ikke at påvirke deres adfærd i ledelsessituationer. I disse er alle mulige former for betingelser og begrænsninger med til at påvirke subjektet. Der er ikke nogen indlysende forbindelse mellem subjektpositionen som mor og subjektpositionen som leder. Alle former for konstruktioner er mulige. En kærlig mor kan meget vel være en krævende og resultatorienteret leder. Der er ingen garanti for, at det feminine, som udtrykkes i familien, også udtrykkes under hårde konkurrencebetingelser. De dominerende kulturelle værdier marginaliserer det feminine i store dele af businessverdenen. I stedet for at promovere et idealiseret billede af kvinden i ledelse i opposition til et misvisende homogent billede af mandlige ledere, kunne vi promovere de værdier, vi mener er vigtige og i øvrigt være meget forsigtige med at kønsstemple disse.

Hvis vi skal stræbe efter forandringer, som rækker ud over at få flere kvindelige ledere, er det radikale forandringer, der skal til, hvor kvalitative (feminine) værdier såsom balance mellem familie og arbejde samt økologisk holdbar udvikling og etisk og social ansvarlighed opgraderes på bekostning af f.eks. produktivitet og overflodskonsumption. Sådanne værdier har ikke været fremført af kvindelige ledere, heller ikke af fortalere for feminin ledelse, sjældent er det mere fundamentale mål og værdier, der udfordres (Calás \& Smircich 1993). Når disse værdier har været på dags- 
ordenen, har det været som resultat af en ændret forbrugerbevidsthed og pres fra forskellige politiske (økologiske) grupper. Økologisk balance og etik i forhold til mennesker, natur og dyr er vigtige kodeord. De er ikke unikke for kvinder. (Der er dog et kønselement her, da mandlig dominans har påvirket, hvordan de teknologiskkapitalistiske institutioner opererer.) Disse (nye) værdier kræver ledere, som ikke kun er formålsrationelle, men som også er intelligente på et mere emotionelt niveau (værdirationelle). Kvaliteter - som at være $\mathrm{i}$ stand til at være mere empatisk, at tænke emotionelt, at lade vore hjerter lede os mere - kan vi naturligvis stemple som bløde og nogle ville sikkert kalde dem feminine. Dette er uheldigt, da de så vil blive betragtet som noget, der er mere eller mindre forbeholdt kvinder, og derfor måske mindre vigtigt. Af den grund og for at kunne pege på nogle bredere problemstillinger end bare at promovere en gruppe af fremtidige kvindelige ledere, bør vi være meget forsigtige med at kønsstemple ledelse og værdier.

\section{Note}

1. Denne artikel er en revideret og forkortet version af 'Questioning the Notion of Feminine Leadership' (se litteraturlisten).

\section{LITTERATUR}

- Alvesson, M. (1998): “Gender relations and identity at work. A study of masculinities and femininities in an advertising agency." Human Relations $51(8)$

- Alvesson, M. \& Billing, Y. D. (1997): Understanding Gender and Organizations. Sage, London.

- Bayes, J. (1987): “Do female managers in public bureaucracies manage with a different voice?" Paper presented at the Third International Interdisciplinary Congress on Women. Dublin

- Billing, Y. D. \& Alvesson, M. (1994): Gender, Managers and Organizations. de Gruyter, Berlin/New York.
• Billing, Y. D. \& Alvesson, M. (2000): "Questioning the Notion of Feminine Leadership: A Critical Perspective on the Gender Labelling of Leadership." Gender, Work and Organization, 7,3.

· Blomqvist, M. (1994): "Könshierarkier i gungning. Kvinnor i kunskapsföretag." Studia Sociologica Upsaliensia 39. Acta Universitatis Upsaliensis, Uppsala.

. Calas, M. \& Smircich, L. (1992): "Re-writing gender into organizational theorizing: directions from feminist perspectives." I: Reed, M \& Hughes, M(Red) Re-thinking Organization: New Directions in Organizational Theory and Analysis. Sage, London.

. Calás, M. \& Smircich, L. (1993): "Dangerous liaisons: the 'feminine-in-management' meets 'globalization'”. Business Horizons. (March-April). . Cheng, C. (1996): "Men and masculinities are not necessarily synonymous: Thoughts on organizational behaviour and occupational sociology." I: Cheng, C. (Red) Masculinities in Organizations. Sage, London.

- Cockburn, C. (1991): In the Way of Women. Macmillan, London.

- Collinson, D. \& Hearn, J. (1996): Men as Managers, Managers as Men. Sage, London.

- Dobbins, G. \& Platz, J. (1986): "Sex differences in leadership: How real are they?" Academy of Management Review, 11.

. Eagly, A. \& Johnson, B. (1990): "Gender and leadership style: a meta-analysis." Psychological Bulletin, 108 (2).

- Eagly, A., Makhijani, M. \& Klonsky, B. (1992):

"Gender and the evaluation of leaders: a metaanalysis." Psychological Bulletin, 111 (1).

- Fagenson, E. A. (1993): "Diversity in Management: Introduction and the Importance of Women in Management." I: Fagenson, E. A. (Red) Women in Management. Trends, Issues, and Challenges in Managerial Diversity. Sage, London.

. Fagenson, E. A. \& Jackson, J. J. (1993): "Final Commentary." I: Fagenson, E. A. (Red) Women in Management.Trends, Issues, and Challenges in Managerial Diversity. Sage,

London.

- Fletcher, J. (1994): "Castrating the female advantage. Feminist standpoint research and management science." Journal of Management Inquiry, 3.

- Fondas, N. (1997): "Feminization unveiled: management qualities in contemporary writings." Academy of Management Review, 22 (1).

- Gagne, P. \& Tewksbury, R. (1996): “No 'Man's' Land: Transgenderism and the Stigma of the Feminine Man." Advances in Gender Research, 1. 
. Grant, J. (1988): "Women as managers: What can they offer to organizations?" Organizational Dynamics. 16 (1).

- Hartsock, N (1987): "The feminist standpoint: developing the ground for a specifically feminist historical materialism." I: Harding, S. (Red) Feminism \& Methodology. Open University Press, Milton Keynes.

. Helgesen, S. (1990): The Female Advantage.

Doubleday, New York.

- Heller, A. (1984): A Radical Philosophy. Basil Blackwell, Oxford.

- Hines, R ( 1992): “Accounting: filling the negative space." Accounting, Organization and Society. 17, 3-4.

· Holmquist, C. (1997): „Den ömma bödeln.

Kvinnliga ledare i

åtstramningstider." I: Sundin, E. (Red) Om makt och kön i sparen av offentliga organisationers omvandling. SOU 1997: 83. Fritzes, Stockholm.

- Kanter, R. M. (1977): Men and Women of the Corporation. Basic Books, New York.

- Kaufmann, M. (1994): "Men, feminism, and men's contradictory experiences of power." I: Brod, H. \& Kaufman, M. (Red) Theorizing Masculinities. Sage, London.

- Keller, E. F. (1985): Reflections on Gender and Science. Yale University Press, New Haven.

· Kerfoot, D. \& Knights, D. (1996): “The best is yet to come? The quest for embodiment in managerial work." I: Collinson, D. \& Hearn, J.

(Red) Men as Managers, Managers as Men. Sage, London.

- Kimmel, M. (1994): "Masculinity as homophobia: Fear, shame and silence in the construction of gender identity." I: Brod, H. \& Kaufman, M. (Red) Theorizing Masculinities. Sage, London. · Kolb, D. (1992): “Women's work: peacemaking in organizations.” I: Kolb, D. \& Bartunek, J. (Red) Hidden Conflict in Organizations. Sage, Newbury Park, CA.

- Lefkowitz, J. (1994): "Sex-related differences in job attitudes and dispositional variables: now you see them." Academy of Management Journal, 37 (2).

- Marshall, J. (1993): “Organizational communication from a feminist perspective." I: Deetz, S. (Red) Communication Yearbook, Vol. 16. Sage, Newbury Park.
- Mills, A (1988): “Organization, gender and culture." Organization Studies, 9 (3).

- Powell, G. N. (1988): Women and Men in Management. Sage, Beverly Hills.

- Rosener, J. B. (1990): "Ways women lead." Harvard Business Review (Nov-Dec).

- Stivers, C (1993) Gender Images in Public Administration.. Newbury Park: Sage

- Townley, B. (1994): Reframing Human Resource Management. Sage, London.

. White, J. (1995): "Leading in their own ways. Women chief executives in local government." I: Itzin and Newman (Red) Strategies for Organizational Change

\section{SUMMARY}

Traditionally, leadership has been equated with masculinity. Managerial jobs have been defined as a matter of instrumentality, autonomy, result-orientation, etc., something which is not particularly much in line with what is broadly assumed to be typical for females. Today, however, there seems to be a broad interest in leadership being more participatory, non-bierarchical, flexible and group-oriented. These new ideas of leadership are often seen as indicating a feminine orientation. This paper argues that it is necessary to critically discuss the whole idea of gender labelling leadership as masculine or feminine and suggests that we are very careful and potentially aware of the unfortunate consequences when we use gender labels. Constructing leadership as feminine may be of some value as contrast to conventional ideas on leadership and management but may also create a misleading impression of women's orientation towards leadership as well as reproduce stereotypes and a traditional gender division of labour.

Yvonne Due Billing, fil.dr, lektor Sociologisk Institut, Københavns Universitet ulønnet docent ved Lunds Universitet 